\title{
Characterization of Overtopping Waves on Sea Dikes with Gentle and Shallow Foreshores
}

\author{
Tomohiro Suzuki ${ }^{1,2, *} \mathbb{D}$, Corrado Altomare ${ }^{3,4}\left(\mathbb{D}\right.$, Tomohiro Yasuda ${ }^{5}\left(\mathbb{D}\right.$ and Toon Verwaest ${ }^{1}$ \\ 1 Flanders Hydraulics Research, 2140 Antwerp, Belgium; toon.verwaest@mow.vlaanderen.be \\ 2 Faculty of Civil Engineering and Geosciences, Delft University of Technology, \\ 2628 CN Delft, The Netherlands \\ 3 Maritime Engineering Laboratory, Department of Civil and Environmental Engineering, \\ Universitat Politecnica de Catalunya-BarcelonaTech (UPC), 08034 Barcelona, Spain; \\ corrado.altomare@upc.edu \\ 4 Department of Civil Engineering, Ghent University, Technologiepark 60, 9052 Gent, Belgium \\ 5 Department of Civil, Environmental and Applied System Engineering, Kansai University; \\ Suita, Osaka 564-8680, Japan; yasuda-t@kansai-u.ac.jp \\ * Correspondence: tomohiro.suzuki@mow.vlaanderen.be; Tel.: +32-3-224-69-34
}

Received: 15 September 2020; Accepted: 25 September 2020; Published: 27 September 2020

\begin{abstract}
Due to ongoing climate change, overtopping risk is increasing. In order to have effective countermeasures, it is useful to understand overtopping processes in details. In this study overtopping flow on a dike with gentle and shallow foreshores are investigated using a non-hydrostatic wave-flow model, SWASH (an acronym of Simulating WAves till SHore). The SWASH model in 2DV (i.e., flume like configuration) is first validated using the data of long crested wave cases with second order wave generation in the physical model test conducted. After that it is used to produce overtopping flow in different wave conditions and bathymetries. The results indicated that the overtopping risk is better characterized by the time dependent $\mathrm{h}$ (overtopping flow depth) and $\mathrm{u}$ (overtopping flow velocity) instead of $\mathrm{h}_{\max }$ (maximum overtopping flow depth) and $\mathrm{u}_{\max }$ (maximum overtopping flow velocity), which led to overestimation of the risk. The time dependent $\mathrm{u}$ and $\mathrm{h}$ are strongly influenced by the dike configuration, namely by the promenade width and the existence of a vertical wall on the promenade: the simulation shows that the vertical wall induces seaward velocity on the dike which might be an extra risk during extreme events.
\end{abstract}

Keywords: wave overtopping; average overtopping discharge; individual volume; overtopping flow depth; overtopping flow velocity; promenade; vertical wall; SWASH

\section{Introduction}

Global climate change has manifold impacts on the ocean and its behavior, which directly translates to the coastal/nearshore region as well as the governing processes. One such climate-induced response is the augmented frequency and intensity of extreme waves, leading to increased overtopping risk for people living in coastal area $[1,2]$. One of the wave overtopping risks for people is direct wave action, which is not only relevant to pedestrians $[3,4]$ and vehicles on a dike/promenade but also to people in front of and inside dwellings and commercial buildings (e.g., hotels and restaurants on dikes). There is some literature related to the stability of people on the dikes/promenade (e.g., [3-5]), which deals with the relationship between human's stability and flow parameters (i.e., overtopping flow depth and flow velocity). Altomare et al. [6] indicated that the combination of overtopping flow velocity and flow depth rather than single maximum values of one of these parameters is required to understand pedestrians hazard. Arrighi et al. $[7,8]$ conducted a numerical study on human's stability 
and highlighted the importance of relative submergence and Froude number to interpret the results. Other works focused on the characterization of overtopping flow depths and/or velocities, see [9-12]. These are important works to understand the basic risk exposed to the flows on dikes, however the present knowledge cannot cover all the risks due to different layouts and hydraulic conditions. In a reality, there are often structures on the dike and thus the overtopping flow characteristics are a bit more complex than the simplified assumptions (e.g., only plain promenade) found in the literature. Overtopping flow can be changed by the interaction with structures. When overtopping is severe, overtopping waves can destroy the facade (i.e., the first defense of the dwellings/apartment buildings, such as windows, see examples in [13]), waves can propagate further even inside buildings. Then, the wave will be reflected to the seaward. The return flow or reflected wave in front of a vertical wall can also influence the human's stability, however a detailed discussion on such different flow directions has not been made explicitly so far.

As such, there are some knowledge gaps in the investigation on the risk of wave overtopping flow on and behind sea dikes together with structures, and therefore it is important to discuss further which physical process is relevant for the risk on people in coastal areas. So far, the safety of pedestrians and vehicles on coastal zones have been evaluated based on average overtopping discharge, maximum individual volume, and associated wave height, see EurOtop [14]. For instance, EurOtop indicates that individual overtopping volume $V_{\max }$ of $600 \mathrm{l} / \mathrm{m}$ in combination with $\mathrm{H}_{\mathrm{m} 0}=1-3 \mathrm{~m}$ is a limit for overtopping for people standing at dikes with clear view of the sea but it does not give further detailed explanation. Those are important indications but the applicability, for example, to the gentle and shallow foreshore cases is still not very clear [15]. Moreover, it is of interest how a fixed criterion (e.g., $1 \mathrm{l} / \mathrm{s} / \mathrm{m}$ or $10 \mathrm{l} / \mathrm{s} / \mathrm{m}$ ) can be linked to the overtopping characteristics such as $\mathrm{V}_{\max }$ (maximum individual volume), and time dependent $h$ (overtopping flow depth) and $u$ (overtopping flow velocity). As Altomare et al. [6] indicated, the combination of $\mathrm{u}$ and $\mathrm{h}$ is linked to the hazard rather than the single maximum values of one of these parameters. According to Suzuki et al. [16], gentle and very shallow foreshore will result in flatter spectrum at the toe of the dike and thus spectral wave period $T_{m-1,0}$ is much longer than ones in deep water conditions due to infragravity waves contribution [17]. In such a situation, the waves have been transformed into bores and therefore overtopping characteristics, namely, flow pattern on dikes /promenades, might be also different from one which toe is at deep water. However, not so many studies have been conducted on the flow characteristics on dikes with gentle and shallow foreshores and discussed the associated risk.

The purpose of this study is to investigate the relationship between the mean discharge, $\mathrm{q}$, and other overtopping parameters $\left(V_{\max }, h_{\max }, \mathrm{u}_{\max }, \mathrm{V}, \mathrm{h}, \mathrm{u}\right)$ on the dike with and without a vertical structure (i.e., a sea wall or a building) with a gentle and shallow foreshore, and eventually to discuss the proper assessment method for overtopping waves. To this end, a non-hydrostatic wave-flow modelSWASH (an acronym of Simulating WAves till SHore) [18] is employed in this study. The model has been validated for the case of wave overtopping over the impermeable dikes with gentle and shallow foreshore configuration [16]. To ensure the applicability of the model to this study, relevant physical model test results from the Climate Resilient Coast project (CREST, http://www.crestproject.be/) are employed for further validation. Using the validated model, flow characteristics on a wide range of different hydraulic and topographic conditions are further investigated. Note that SWASH can provide not only time dependent wave surface elevation but also velocity field. By post-processing, it is possible to calculate individual overtopping volumes and average overtopping discharge too. Obtaining such outputs, especially the velocity fields on the dike, is not an easy task in physical models since the velocity measurement points are exposed to wet and dry conditions (when overtopping happens the bottom becomes wet while in the other moments the bottom is in general dry) which is often a problem for velocimeters and thus numerical simulation is a good alternative to study overtopping hazard. 


\section{Methods}

\subsection{SWASH}

SWASH is based on non-linear shallow water equation with non-hydrostatic pressure terms. The model can be run either in depth averaged mode or multi-layer mode. It is possible to maintain frequency dispersion by increasing the number of layers. A model with two or three layers already provides enough accuracy in terms of the frequency dispersion for most of the coastal applications. Combining with HFA (hydrostatic front approximation [19]) the model can deal with wave breaking with enough accuracy even in such a limited number of vertical layers. On top, non-linear wave properties under breaking waves (e.g., asymmetry and skewness) are preserved. See more details in [18].

The features that SWASH offers, namely maintaining a good accuracy of wave transformation and overtopping and is computationally not too demanding, are important factors for this study since the model needs to capture the overtopping process on the sea-dike and at the same time it is necessary to repeat calculations with different bathymetries, different water levels and wave conditions. SWASH is computationally less demanding and thus it is easy to run a long duration (i.e., 1000 waves) and a large number of calculations. One drawback of the SWASH model is that it cannot deal with a complex structure such as a parapet.

\subsection{Model Settings}

All the simulations are carried out in 2DV (two dimensional vertical). The version of the model applied in this study is version 5.0. The grid size in the horizontal direction is $0.5 \mathrm{~m}$ in the prototype scale as recommended in [20] which ensures a good wave propagation and overtopping processes. The threshold water level (DEPMIN) is set $0.001 \mathrm{~m}$ for the prototype calculation, which increases the computational stability compared to the default value. Two layers of equidistant layer distribution are employed in this simulation in order to maintain good frequency dispersion and the accuracy of second order wave generation [21], so-called infragravity waves, which plays an important role for wave run-up and overtopping process. Note that it is still possible to use one layer in light of linear dispersion since the kh value of the test is less than 2.9 as indicated in the user manual. However, two layers are better for the accuracy of the wave generation and propagation. Internal wave generation [22] has not been used in this study since the reflection from the structure is very limited in this case.

As for the numeric, the Keller-box scheme is used for the simulation since the number of the vertical layer is two. ILU (incomplete lower-upper factorization) preconditioner is employed for the computational robustness.

The momentum scheme is moment conservative. The standard first order up-wind scheme is used for the discretization of the vertical term for w-momentum equation for the sake of stability of the computation, while other discretization (i.e., the horizontal and vertical terms for u-momentum equation and the horizontal term for w-momentum equation) used MUSCL (monotonic upstream-centered scheme for conservation laws) limiter to achieve second order accuracy. Time integration is explicit and a maximum Courant number of 0.5 is used to cope with high and nonlinear waves used in this study.

The Manning formula with a Manning coefficient of $0.019 \mathrm{~m}^{-1 / 3} \mathrm{~s}$ is employed to represent bottom friction for the entire domain, both for sandy beach and the dike. Note that $0.019 \mathrm{~m}^{-1 / 3} \mathrm{~s}$ is the recommended value for wave simulations in the user manual. This must be due to the fact that the Manning's coefficient for sand (e.g., the grain size of $0.3-0.4 \mathrm{~mm}$ ) is around this value. For the dike it is assumed that the bottom of the promenade is often like unfinished concrete, and which Manning's coefficient is around $0.014-0.020 \mathrm{~m}^{-1 / 3} \mathrm{~s}$ and thus $0.019 \mathrm{~m}^{-1 / 3} \mathrm{~s}$ should be an acceptable choice. Standard wave breaking control parameters, alpha $=0.6$ and beta $=0.3$, are used for wave breaking, and those values are also used in [16]. 


\subsection{Test Matrix}

As stated earlier, the purpose of the numerical experiment in this study is to understand the overall overtopping flow characteristics on the dike and in front of / inside buildings for a wide range of the overtopping discharge values. Therefore, the test matrix is designed to be able to obtain 4 different orders of magnitude of wave overtopping discharges, namely $0.1,1,10$, and $100 \mathrm{l} / \mathrm{s} / \mathrm{m}$. The range of average overtopping discharges is achieved by changing the input hydraulic conditions (i.e., water levels, offshore significant wave height) and bathymetries (i.e., toe level, dike crest level, promenade width). The results will be further processed to discuss which physical parameter is relevant to the risk of people at the coast. In total 96 cases for each configuration ( $Q$ and $W$ ) of the numerical experiment have been conducted. For all the numerical experiments, a fixed seed number is used, and the number of waves is 1000 .

Table 1 shows the test matrix. The case name is specified according to the input conditions, e.g., RSK_Q_7_3_12_65_85_00. See the next section for the detailed setting of the bathymetry.

Table 1. Variation of test parameters and the values.

\begin{tabular}{cccccccc}
\hline $\begin{array}{c}\text { Name } \\
{[-]}\end{array}$ & $\begin{array}{c}\text { Bathymetry } \\
{[-]}\end{array}$ & $\begin{array}{c}\text { Water } \\
\text { Level }[\mathbf{m}]\end{array}$ & $\begin{array}{c}\mathbf{H}_{\mathbf{m} 0} \\
{[\mathbf{m}]}\end{array}$ & $\begin{array}{c}\mathbf{T}_{\mathbf{p}} \\
{[\mathbf{m}]}\end{array}$ & $\begin{array}{c}\text { Toe Level } \\
{[\mathbf{m}]}\end{array}$ & $\begin{array}{c}\text { Dike Crest } \\
\text { Level }[\mathbf{m}]\end{array}$ & $\begin{array}{c}\text { Promenade } \\
\text { Width [m] }\end{array}$ \\
\hline RSK & $\mathrm{Q}$ & $22(7)^{1}$ & 3 & 12 & $21.5(6.5)^{1}$ & $23.5(8.5)^{1}$ & 0 \\
& $\mathrm{~W}$ & $23(8)^{1}$ & 4 & & $21.9(6.9)^{1}$ & $24.0(9.0)^{1}$ & 20 \\
& & 5 & & & $24.5(9.5)^{1}$ & \\
& & & & & & $25.0(10.0)^{1}$ & \\
\end{tabular}

${ }^{1}$ The value inside the brackets is based on [m TAW] (Tweede Algemene Waterpassing; Belgian standard datum level, situated near MLLWS) and the value is reflected in the case name.

\subsection{Bathymetry}

The level of the flat bottom in front of the wave generator is $0 \mathrm{~m}(-15 \mathrm{~m}$ TAW) and the length is $200 \mathrm{~m}$ : it is slightly longer than one offshore wave length. The foreshore slope is fixed at 1/35 up to the dike toe at 21.5 and $21.9 \mathrm{~m}$ ( 6.5 and $6.9 \mathrm{~m} \mathrm{TAW})$. The slope of the dike is $1 / 2$ and the promenade is $1 / 50$. This is the base bathymetry which is applicable to both configurations (i.e., bathymetry $\mathrm{Q}$ and $\mathrm{W}$ ).

Tests with bathymetry $\mathrm{Q}$ is aimed to obtain flow and overtopping properties (i.e., $h, u, V, q$ ) at the end of the promenade for both $0 \mathrm{~m}$ and $20 \mathrm{~m}$, and thus no vertical wall at the end of them. Tests with bathymetry $\mathrm{W}$ is aimed to obtain overtopping flow properties (i.e., $h, u$ ) in front of a vertical wall on the promenade.

Figure 1 shows the sketch of each bathymetry $\mathrm{Q}$ and $\mathrm{W}$ with different promenade width. The diamond points indicate the measurement points of flow and overtopping properties.
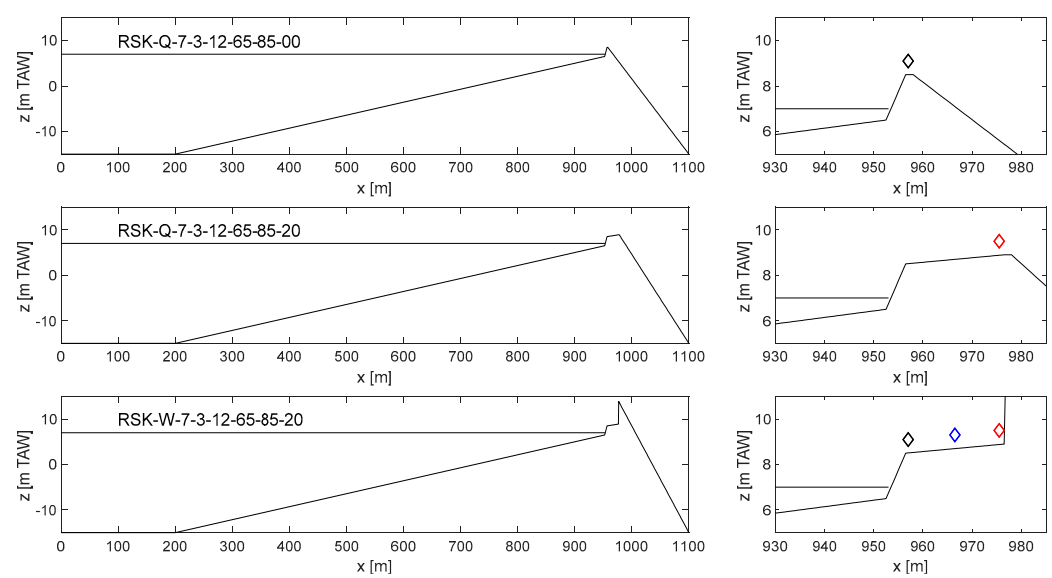

Figure 1. Bathymetries (type $\mathrm{Q}$ and $\mathrm{W}$ ) and measurement points (black points: beginning, blue point: middle, red points: end of the promenade). 


\subsection{Post-Processing}

In SWASH, two equidistant layers are used for this simulation and the flow parameter $\mathrm{u}$ to be used in this study is the averaged value of the two velocities of the two layers.

In order to calculate the individual overtopping volume, a water level criterion of $0.01 \mathrm{~m}$ is applied as a threshold. When the overtopping flow depth does not exceed this value, the overtopping is not counted as one overtopping event.

$\mathrm{V}, \mathrm{h}$ and $\mathrm{u}$ are the time dependent parameters, however, in order to discuss overtopping hazard, maximum values during 1000 waves' test are used and they are expressed as $V_{\max }, h_{\max }$ and $u_{\max }$, respectively. The values are the maximum ones, so it is sensitive to the exceedance probability: when a lower number of waves are applied, the maximum value will be lower.

\subsection{Physical Model}

To validate the numerical model, we employed data from a physical model test campaign carried out in Belgium within the framework of the CREST project, see also the details in [23]. All the relevant data set to this study comprise average overtopping discharge and individual volume measured at the end of dike slope (i.e., only promenade width $0 \mathrm{~m}$ ). Since the SWASH model to be used in this study is run in 2DV (i.e., flume like configuration) based on the second order wave generation, only cases with long crested waves and second order generation from the 3D wave basin physical model are used for the validation. The bottom configuration of the physical model is not exactly the same as one in numerical model (Figure 2), however the main features of the physical model test such as the water depth and the main bottom slope and the dike slope are the same as this numerical experiment. The numerical experiment has a wide range of different configurations (i.e., toe level $\times 2$; dike crest level $\times 4$, and promenade width $\times 2$ ) and it includes the case of physical model (toe $6.5 \mathrm{~m}$ TAW, and dike crest $9.0 \mathrm{~m} \mathrm{TAW}$, promenade $0 \mathrm{~m}$ ).

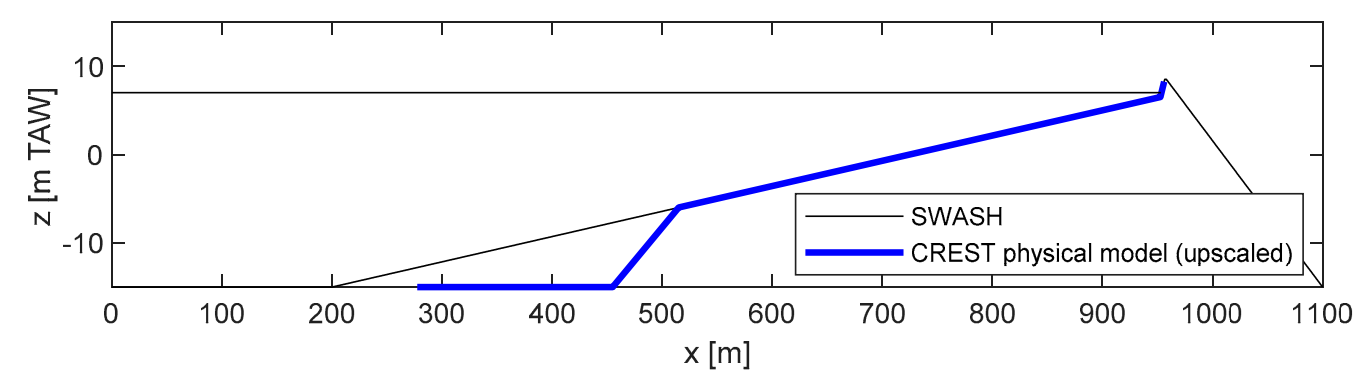

Figure 2. Comparison of the cross section of foreshore and dike profile between the SWASH model and the CREST physical model.

\section{Results}

\subsection{Validation}

The physical model test results of maximum individual overtopping volume $V_{\max }$ (data only limited to long crested and second order wave generation cases) are further processed and linked to the average overtopping discharge, see Figure 3. See [24] for further details of the data processing.

As can be seen in the figure the maximum individual overtopping volumes estimated by SWASH are in line with the physical model data. As shown in [25], SWASH can represent not only mean overtopping discharge over the dikes, but also wave run-up processes such as overtopping flow depth and velocity on the promenade, and wave force acting on a vertical wall on a dike. Therefore it can be concluded that the SWASH model is accurate enough. It is possible to explore further the wave overtopping characteristics on a dike with gentle and shallow foreshores based on the model. 


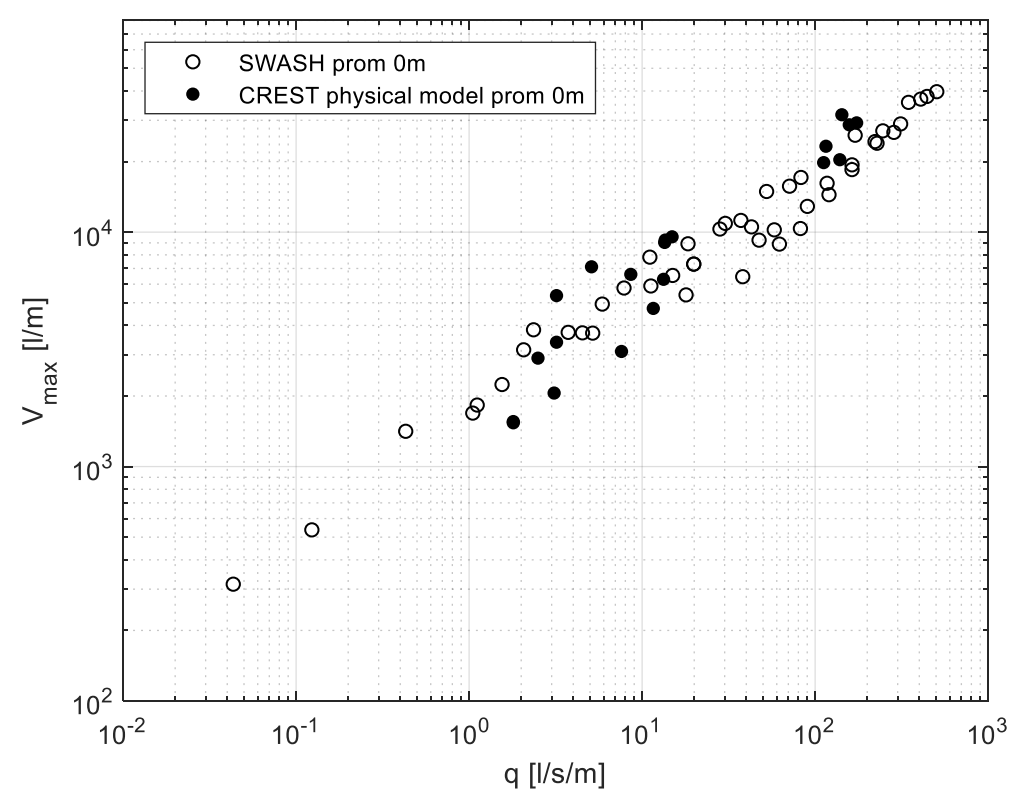

Figure 3. Comparison between SWASH and physical model on $\mathrm{q}-\mathrm{V}_{\max }$ (Average overtopping discharge-maximum individual overtopping volume) for the case of promenade width $0 \mathrm{~m}$.

\subsection{Overtopping Flow Characteristics on a Promenade (without a Vertical Wall)}

In this section, overtopping flow properties on a promenade is investigated by SWASH. The used bathymetry is type $Q$, and thus there is no wall at the end of the promenade. This numerical experiment gives insights concerning how overtopping flow properties which are not disturbed by a vertical wall behave on the slightly sloped promenade.

\subsection{1. $\mathrm{q}-\mathrm{V}_{\max }$ Relationship}

The relationship between $\mathrm{q}$ and $\mathrm{V}_{\max }$ (maximum individual volume) for the cases with promenade width 0 and $20 \mathrm{~m}$ is shown in Figure 4.

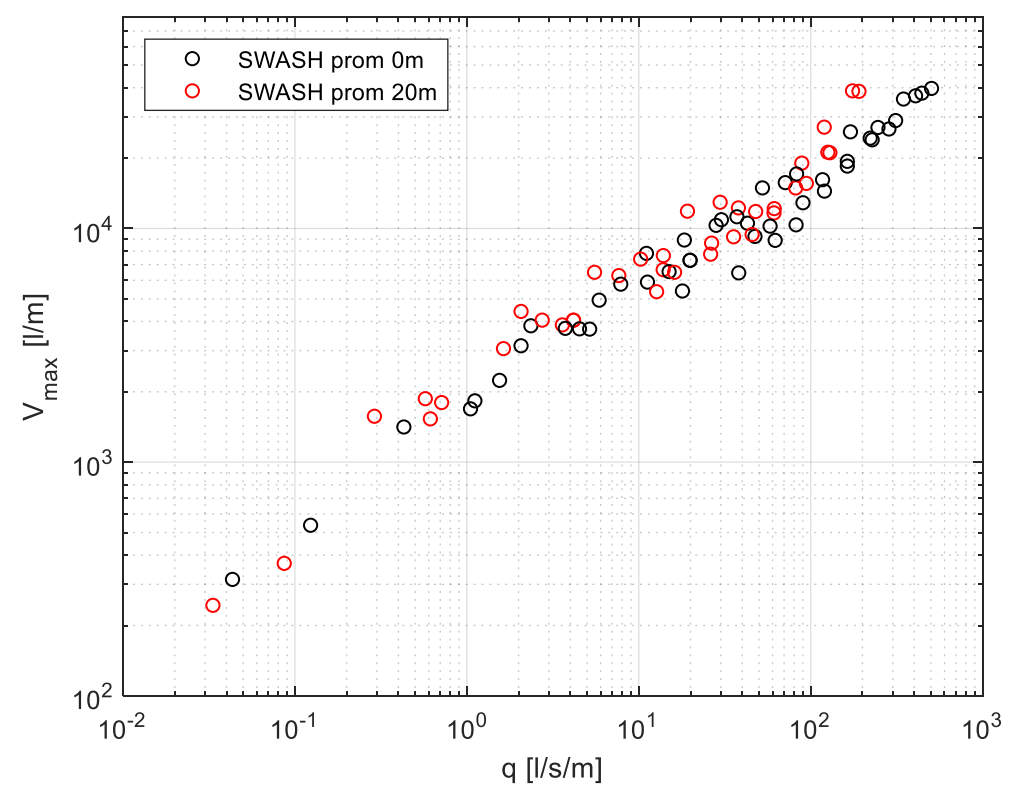

Figure 4. Comparison between promenade width $0 \mathrm{~m}$ and $20 \mathrm{~m}$ on $\mathrm{q}-\mathrm{V}_{\max }$ (Average overtopping discharge-maximum individual overtopping volume). 
As shown in Figure 4,1 1/s/m gives maximum individual volume $V_{\max }$ around $2000 \mathrm{l} / \mathrm{m}$, and $10 \mathrm{l} / \mathrm{s} / \mathrm{m}$ gives $V_{\max }$ around $6000 \mathrm{l} / \mathrm{m}$ for both promenade cases: there is no significant difference between the two promenade widths. From this result it can be concluded that $V_{\max }$ is determined by $q$ in the gentle and shallow foreshore case and the promenade width does not make significant difference on $q-V_{\max }$ relationship for the wide range of the input hydraulic conditions and bathymetries. Even though Allsop et al. [5] indicated that the maximum individual overtopping volumes are more suitable hazard indicators, yet in this case $V_{\max }$ and $q$ both give the same information. This might be due to the fact that the incident significant wave height in this shallow foreshore case is not significantly different at the toe of the dike (toe depth is $0.5 \mathrm{~m}$ ) for different offshore wave conditions: wave height is limited by the shallow water depth.

3.2.2. $\mathrm{q}-\mathrm{h}_{\max }$ and $\mathrm{q}-\mathrm{u}_{\max }$ Relationships

Next, the relationship $\mathrm{q}-\mathrm{h}_{\max }$ (maximum overtopping flow depth) and $\mathrm{q}-\mathrm{u}_{\max }$ (maximum overtopping flow velocity) for the cases with promenade width 0 and $20 \mathrm{~m}$ are shown in Figure 5.
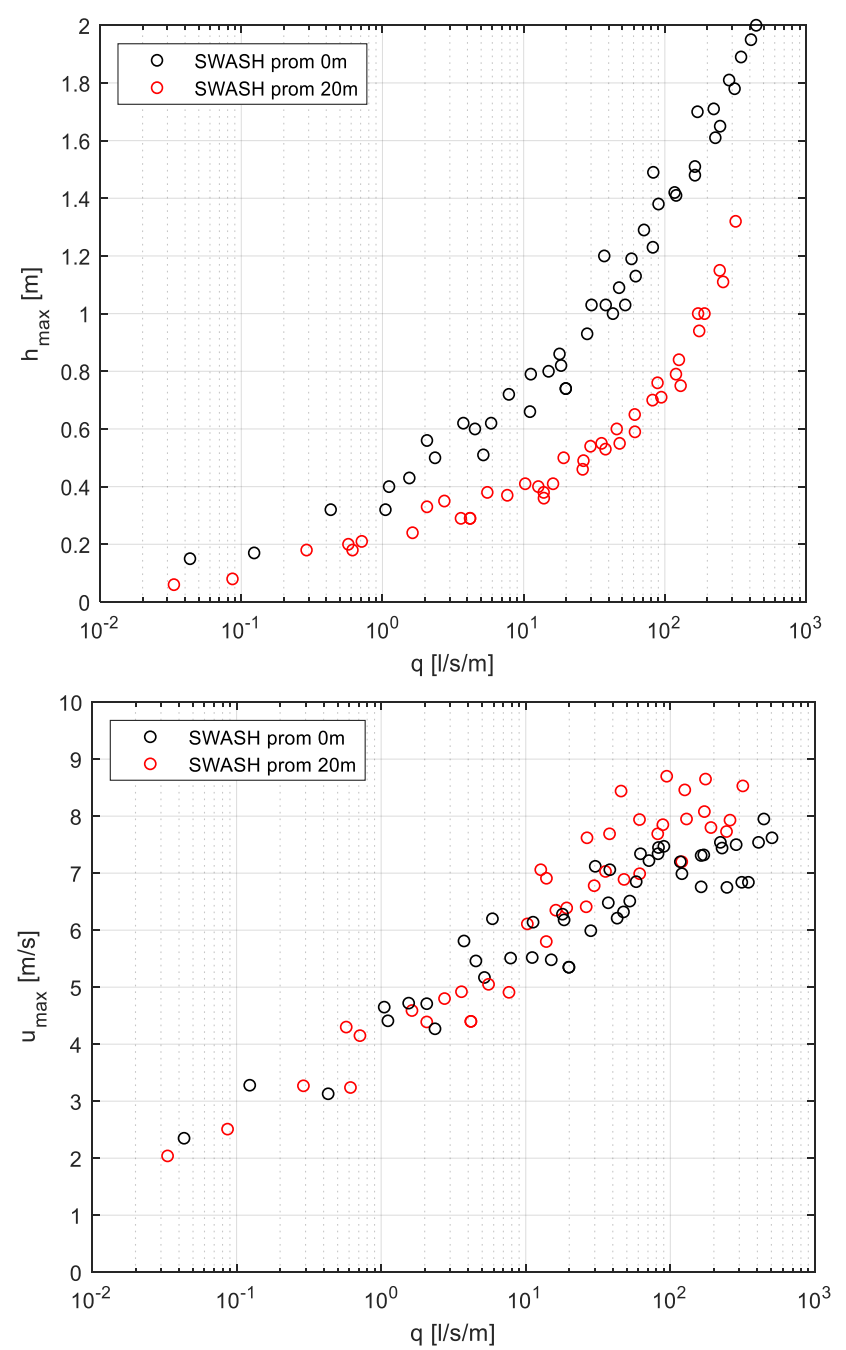

Figure 5. Comparison between promenade width $0 \mathrm{~m}$ and $20 \mathrm{~m}$ on $\mathrm{q}-\mathrm{h}_{\max }$ (upper figure) and $\mathrm{q}-\mathrm{u}_{\max }$ (lower figure).

As shown in the figure of $q-h_{\max }$, the difference of $h_{\max }$ between promenade width $0 \mathrm{~m}$ and $20 \mathrm{~m}$ is significant: to up $\sim 100 \mathrm{l} / \mathrm{s} / \mathrm{m}$ the ratio is almost 2. Looking at the figure of $\mathrm{q}-\mathrm{u}_{\max }$, the difference of the maximum velocity is not significant unless the highest overtopping discharges around $\sim 100 \mathrm{l} / \mathrm{s} / \mathrm{m}$. 


\subsubsection{Time Evolution of Overtopping Flow Characteristics}

It is interesting that on one hand the $\mathrm{q}-\mathrm{V}_{\max }$ gives very similar relationship between different promenade widths and on the other hand $\mathrm{q}-\mathrm{h}_{\max }$ shows a strong influence of the promenade width. In order to understand these differences, the time series of flow properties (time dependent overtopping flow depth $\mathrm{h}$, velocity $\mathrm{u}$ and acceleration) under an overtopping event of similar $\mathrm{V}$ (both case around $1000 \mathrm{l} / \mathrm{m}$, see Table 2) is visualized in Figure 6. Note that the $\mathrm{V}$ in this specific example is not $\mathrm{V}_{\max }$ (maximum overtopping volume) in each case. In addition to $u$ and $h$, the drag and inertia force acting on a person standing on the promenade is also calculated using the Morison equation since time evolution of the forces will be more relevant to the stability of a person standing on a promenade. In this case, two times of a cylinder with the diameter of $0.1 \mathrm{~m}$ are used to representing a person with two legs. Due to the nature of the equation, importance of $\mathrm{u}$ is higher than $\mathrm{h}$ (cfr. $\mathrm{F}$ is proportional to $\mathrm{u}^{2}$ and $\mathrm{h}$ ). As can be seen, the drag force is dominant and the inertia force is somewhat smaller in this case.

Table 2. Individual overtopping volumes for selected cases.

\begin{tabular}{ccc} 
Case & Promenade Width [m] & V \\
{$[-]$} & {$[1 / \mathbf{m}]$} \\
\hline RSK_7_5_12_69_00_00 & 0 & 1043 \\
RSK_7_5_12_65_95_20 & 20 & 1109 \\
\hline
\end{tabular}
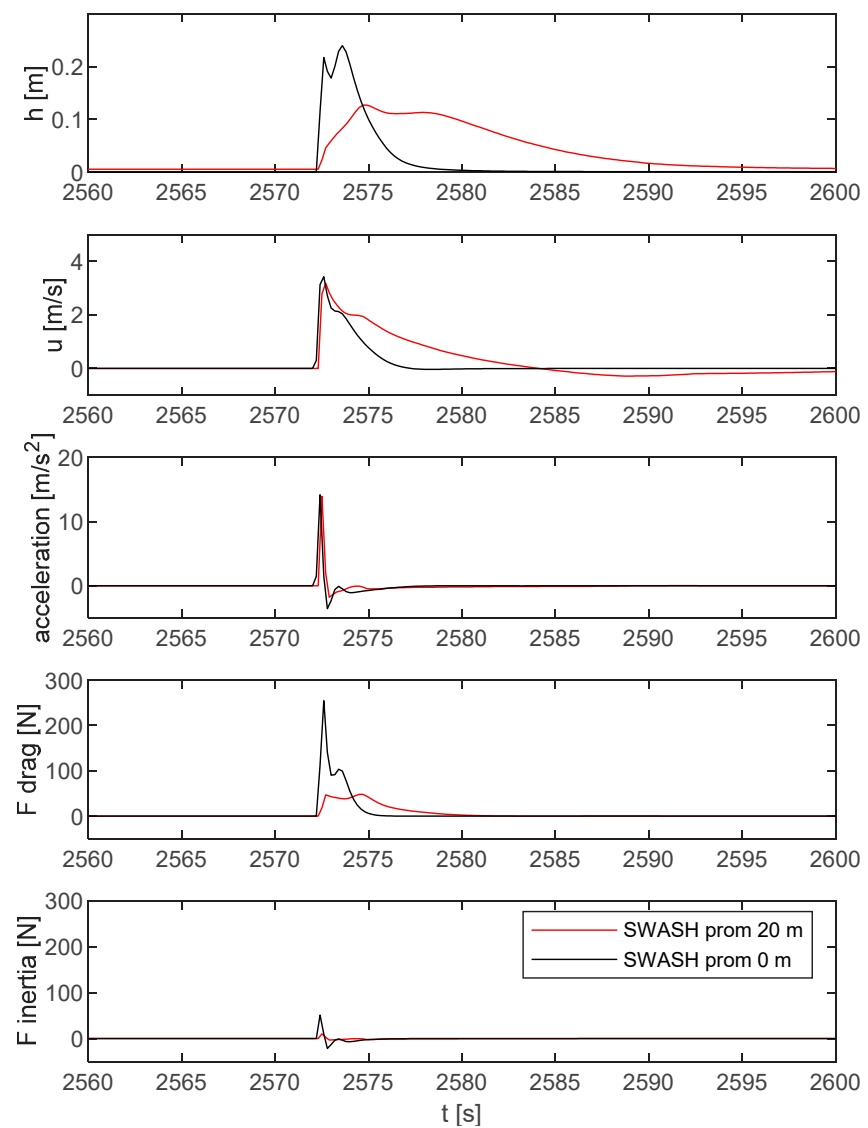

Figure 6. Time series of $h, u$, acceleration, F_drag and F_inertia for the case which $V$ is around 1000 1/m (the red lines are slightly shifted to be able to compare with the black lines easily).

From Figure 6, it is obvious that the flow depth of the case with promenade width $0 \mathrm{~m}$ gives a higher peak while the flow duration is significantly different. The overtopping of the case with promenade width $20 \mathrm{~m}$ lasts about four times longer than one in promenade $0 \mathrm{~m}$ and this is how it gives 
the similar V. The overtopping flow depth of the overtopping waves is decreasing due to the gravity acting on the overtopped bore when it is propagating over the promenade. These relationships indicate that the overtopping flow depth and flow velocity will be more relevant to describe the overtopping hazard compared to the individual overtopping volume $\mathrm{V}$, in the case of gentle and shallow foreshores.

Risk on pedestrians on the promenade is often evaluated by the overtopping flow depth and flow velocity [3-5]. Those are relevant parameters for the stability of a person exposed to the flows: the higher flow depth and flow velocity the lower the stability of a person. However, looking at Figure 6, one can see that the timing of the maximum layer thickness and layer velocity of the selected time window is different. This indicates that only the combination of the maximum values does not describe the hazard properly.

\subsubsection{Overtopping Flow Characteristics and Stability}

Stability is one of the key factors for the safety of the people. Endoh and Takahashi [3] discussed the human stability taking into account different human instability mode, slipping and tumbling. Sandoval and Bruce [4] revisited it taking into account the buoyancy and its position, and shows different criteria by ages and genders. The dashed line shown in Figure 7 is criterion for a tall adult. The criterion is expressed as a line by the combination of $u$ and $h$. However, as explained earlier, in general $u_{\max }$ and $h_{\max }$ do not occur at the exactly same moment (there is a time-lag). If one wants to check stability properly, then it is advised to use a model which can describe the combination of $u$ and $\mathrm{h}$ in a time series. The red line shows the time series of the $\mathrm{u}$ and $\mathrm{h}$ obtained at the end of the $20 \mathrm{~m}$ promenade from the SWASH model. Since it is based on 1000 waves, the line goes the same trajectory many times. The case shown in the figure corresponds to $16.2 \mathrm{l} / \mathrm{s} / \mathrm{m}$ with $\mathrm{V}_{\max }=6491 \mathrm{l} / \mathrm{m}$ and the highest part the of the time dependent $\mathrm{u}$-h line is located at the edge of the stability curve. In case the stability is evaluated by stand-alone $h_{\max }$ (horizontal red dotted line) in combination with stand-alone $\mathrm{u}_{\max }$ (vertical red dotted line), then the hazard is overestimated as can be seen in the figure.

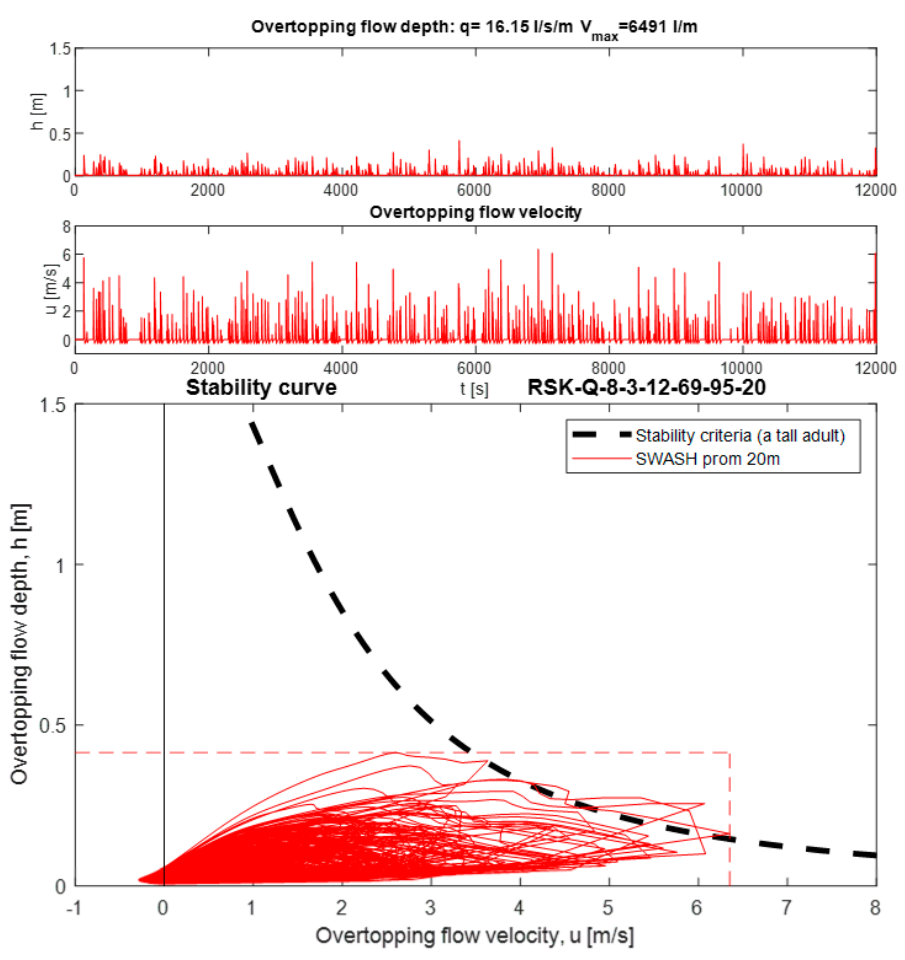

Figure 7. Time series of $\mathrm{h}$ and $\mathrm{u}$ (the first and second figures) and $\mathrm{h}-\mathrm{u}$ relationship calculated in SWASH versus stability curve of a tall adult (the third figure): RSK_Q_8_3_12_69_95_20 00 (a case in which V is around $6500 \mathrm{l} / \mathrm{s} / \mathrm{m}$, and the promenade width of $0 \mathrm{~m}$ ). 
Figure 8 shows a case with very similar $q$ and $V_{\max }\left(q=15.0 \mathrm{l} / \mathrm{s} / \mathrm{m}\right.$ and $\left.V_{\max }=6535 \mathrm{l} / \mathrm{m}\right)$ but the promenade width is $0 \mathrm{~m}$. In this case the h-u line exceeds the stability curve clearly and thus the risk is higher. This is the same observation as described in Section 3.2.3: the overtopping hazard is not always a function of the overtopping discharge nor maximum individual overtopping volume, but on the $\mathrm{u}$ and $\mathrm{h}$ (in the gentle and shallow foreshore case at least).

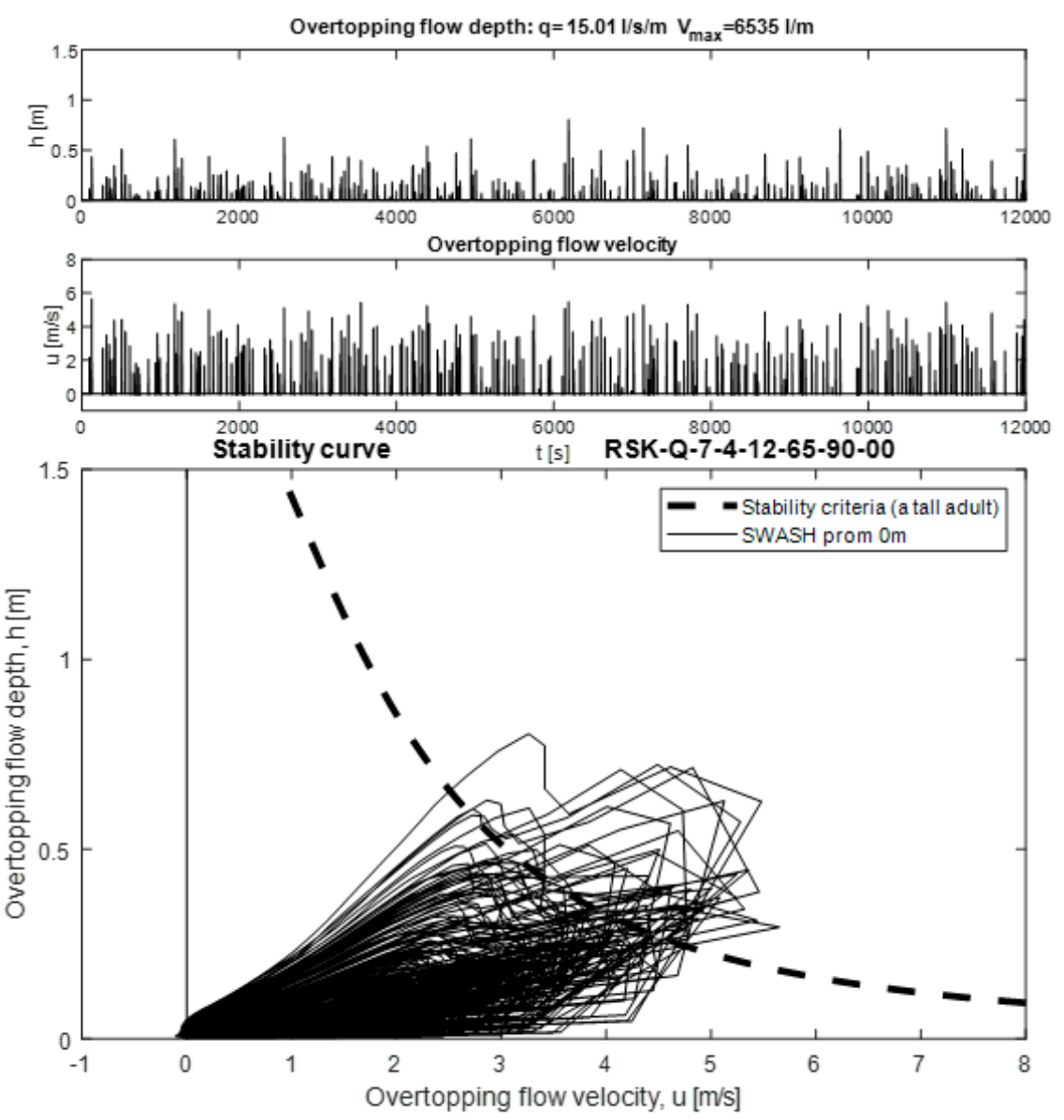

Figure 8. Time series of $\mathrm{h}$ and $\mathrm{u}$ (the first and second figures) and h-u relationship calculated in SWASH versus stability curve of a tall adult (the third figure): RSK_Q_7_4_12_65_90_00 (a case in which V is around $6500 \mathrm{l} / \mathrm{s} / \mathrm{m}$, and the promenade width of $0 \mathrm{~m}$ ).

\subsection{Overtopping Flow Properties in Front of a Vertical Wall}

In case there is a vertical wall at the end of the promenade, waves are reflected at the wall and go back to the sea. Figure 9 shows the h-u time series of the same wave case in Figure 7 but with a vertical wall at the end of the promenade. Note that the h-u output point is just in front of the vertical wall. As can be seen in the figure, the water level (i.e., h) in front of the wall becomes very high due to the reflection. The height becomes more than two times of the one in the case without a vertical wall. Actually, the incident waves are not any more the shape of the wave but a bore, and thus the wave height can exceed two times of the incident wave height (cfr. standing wave). Especially at the end of the promenade, the duration of the bore becomes much longer (e.g., four times longer than one in the case of promenade width $0 \mathrm{~m}$ ), as explained in Section 3.2.2. Thus the flow of the long bore locks up the water mass in front of the vertical wall and eventually the water level becomes much higher (the highest level $\mathrm{h} \sim 1.3 \mathrm{~m}$ ) than the incident bore height (the highest level $\mathrm{h} \sim 0.5 \mathrm{~m}$ ). During this process, the h-u line exceeds the stability curve significantly. It is an example of extra possible risk in the overtopping on the promenade: a structure can increase the hazard. When it reached the highest 
water level, the velocity becomes around zero, and then the reflected waves go back to the sea as if it is a dam break flow.
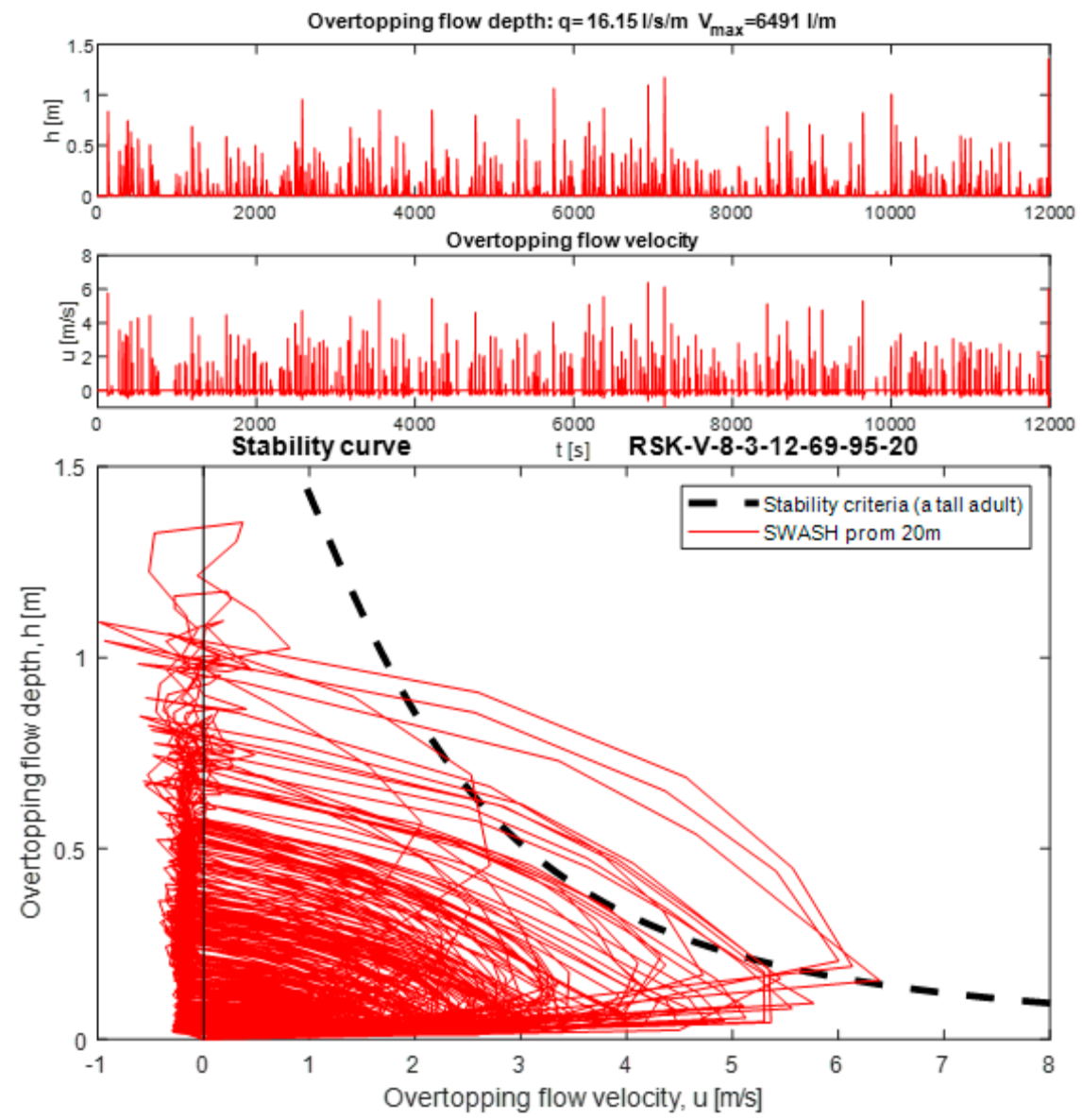

Figure 9. Time series of $h$ and $u$ (the first and second figures) and h-u relationship calculated in SWASH versus the stability curve of a tall adult (the third figure): RSK_W_8_3_12_69_95_20 (a vertical wall case corresponding to the case in which $\mathrm{V}$ is around $6500 \mathrm{l} / \mathrm{s} / \mathrm{m}$, and the promenade width of $20 \mathrm{~m}$ ).

Figure 10 shows the two extra time series of $h-u$. The blue line shows $h-u$ at the middle of the promenade and the black line shows $\mathrm{h}-\mathrm{u}$ at the beginning of the promenade. These lines exceeded the stability curve for the incident bore since these are located more seaside. However extra attention is necessary at the $\mathrm{h}-\mathrm{u}$ line for the return flow (i.e., line where $\mathrm{u}<0 \mathrm{~m} / \mathrm{s}$ ). The negative velocity at the middle of the promenade exceeds $2 \mathrm{~m} / \mathrm{s}$ and one at the beginning of the promenade exceeds $3 \mathrm{~m} / \mathrm{s}$ in this case. Even though the return flow does not reach to the mirrored stability curve, but the values are not small: a person already fallen down due to the incident bore can be pulled into the sea by the return flow. 


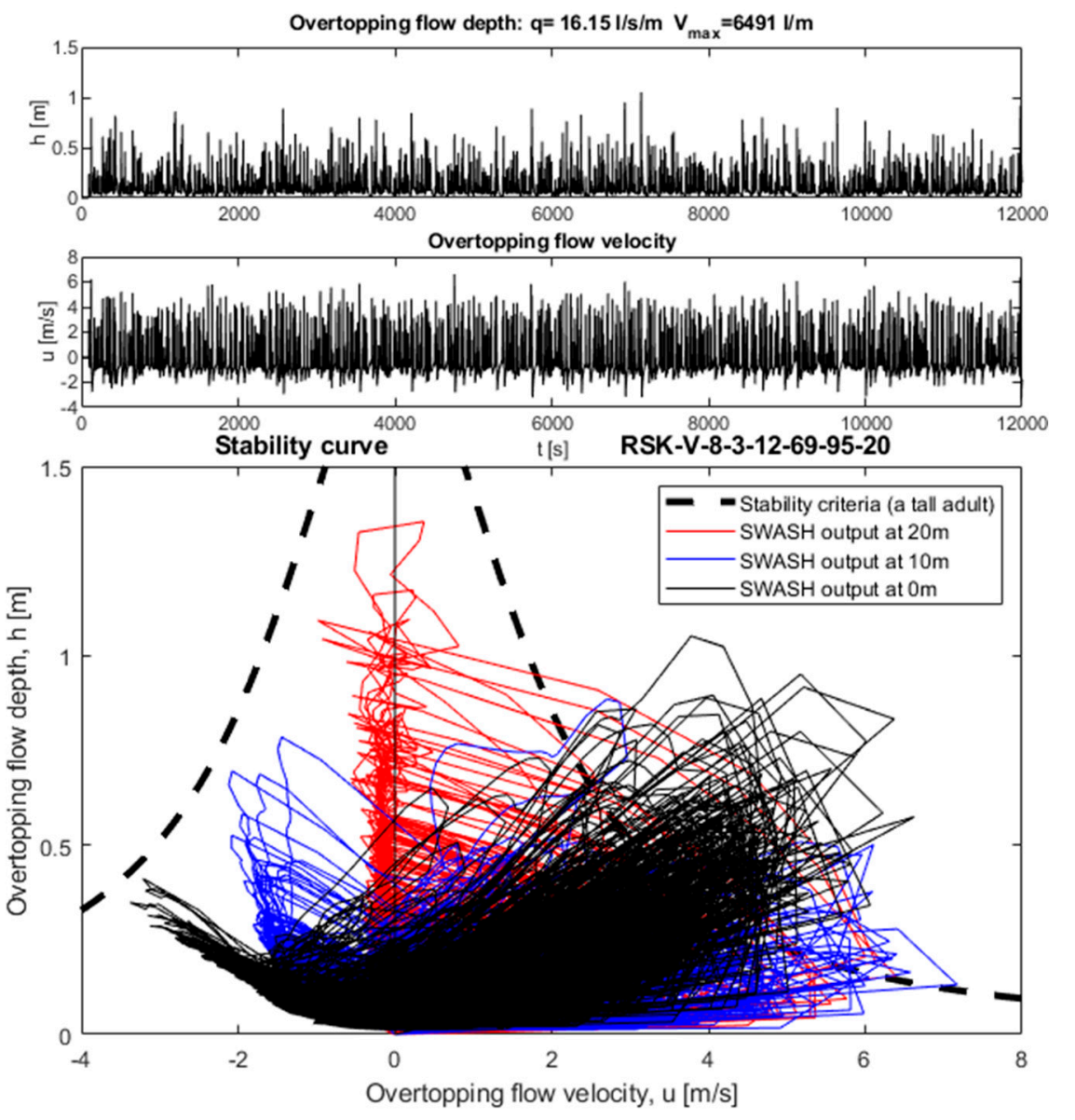

Figure 10. Time series of $h$ and $u$ (the first and second figures) and $h-u$ relationship calculated in SWASH versus the stability curve of a tall adult (the third figure) at 3 output points: RSK_W_8_3_12_69_95_20 (a vertical wall case corresponding to the case in which $\mathrm{V}$ is around $6500 \mathrm{l} / \mathrm{s} / \mathrm{m}$, and the promenade width of $20 \mathrm{~m}$ ).

\section{Discussion}

\subsection{On Accuracy of the Model}

In this study, the validated model is used to derive $u$ and $h$. The accuracy of the model in terms of wave transformation and run-up on the dike is confirmed in [16,25]. Looking into [16], the overtopping estimation has a certain scatter especially when $\mathrm{q}$ is small. However, further validation using the CREST data confirmed the relationship between $q$ and $V_{\max }$, which shows an excellent match to the physical model test data. Note that the accuracy of $h$ and $u$ in time domain has not been confirmed yet in the present study.

The modelling is conducted in 2DV and thus the directional spreading effect is not included. The wave propagation and interaction process with the reflected waves in $3 \mathrm{D}$ is different from in 2DV as shown in [23]. The directional spreading effect is twofold - one is wave transformation from offshore to the toe, and the other one is from the toe to the end of the dike slope where overtopping is measured [6]. In this study mean overtopping discharge $q$ and maximum individual volume $V_{\max }$ are compared for promenade $0 \mathrm{~m}$ and $20 \mathrm{~m}$ cases. However, the influence of the directional spreading is expected to be limited because the relation between $q$ and $V_{\max }$ is similar. The green points depicted in Figure 11 show the $\mathrm{q}-\mathrm{V}_{\max }$ relationship from the CREST physical model where directional spreading is greater than 0 degree (i.e., 12, 16, 20, and 31.5 degrees). As can be seen, the green points are shown in the cloud of the black points (i.e., directional spreading is zero) while the majority of the green points are located in the lower part of the entire cloud. Strictly speaking directional spreading effect on $\mathrm{q}-\mathrm{V}$ 
can be different for the case of $20 \mathrm{~m}$ promenade since the oblique wave can make the overtopping trajectory longer than one of perpendicular attack, namely the effective promenade width will be longer. When the width of the promenade is longer, the $\mathrm{V}$ can be slightly smaller.

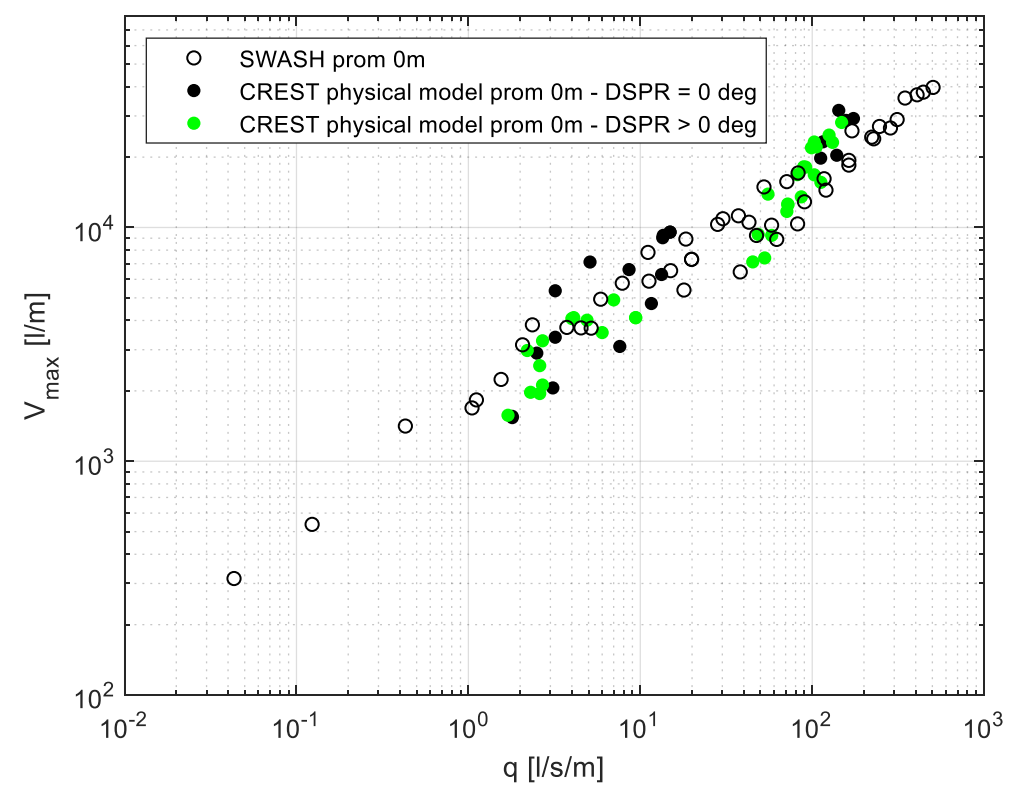

Figure 11. Comparison between DSPR $=0$ and DSPR $>0$ of physical models on $q-V_{\max }$ (Average overtopping discharge - maximum individual overtopping volume) for the case of promenade width $0 \mathrm{~m}$.

\subsection{On the Overtopping Parameters}

Needless to say that $q$ and $V_{\max }$ are still very important parameters to have the first idea to estimate how severe will be the overtopping event. However, time dependent value $u$ and $h$ are more relevant to understand the risk on the dike in details as shown in this study. These parameters have a direct link to the stability of a person. On top of these parameters, acceleration (a) and overtopping event duration $\left(t_{0}\right)$ can be also parameters to give extra information to characterize the overtopping flow on a dike: acceleration in combination with $\mathrm{h}$ can give extra forcing of inertia and duration is also a useful parameter to understand how the overtopping is distributed in time.

\subsection{On the Risk}

Oppenheimer et al. [26] identified six sea level rise (SLR) scenarios. Some of them indicated to have structures in front of the properties to defend from the SLR. From the present study, it became clear that the time dependent $h$ and $u$ needs to be evaluated on top of average overtopping discharge and $\mathrm{V}_{\max }$, in order to understand the risk. Apparently the influence of the promenade is positive in a sense that it reduces not only q but also $h$, as also indicated in [6]. Eventually, the forcing on pedestrians, vehicles, and structures will be reduced due to the effect of the promenade. The effect can be strengthened if extra obstacles are placed on top of the promenade, for instance sea walls and vegetation. The key will be how to reduce $q$ and $V_{\max }$ and also make overtopping event duration $\left(t_{0}\right)$ longer, so that h-u line stays in a small range.

The forcing on the structure is governed by the hydrodynamics [27]. In this study, the façade is assumed to be broken. However, if the façade is strong enough the safety of the people inside the building is maintained. According to Streicher [28], the force acting on a vertical wall on the promenade can be the quasi-hydrostatic in the gentle and shallow foreshore case. Therefore, the force in such case can be estimated roughly if $\mathrm{h}_{\max }$ is known. One of the effective evacuation strategies is the vertical evacuation, however in order to make sure this evacuation method is safe, first the stability of 
the building needs to be guaranteed. That is the reason why estimation of force acting on a building is necessary. Suzuki et al. [25] indicated that SWASH is also capable to estimate F on a vertical structure, but it is not explored in this study. In case detailed hydrodynamics needs to be obtained for complex structures, detailed hydrodynamic modelling (e.g., $[29,30])$ will be an alternative.

\section{Conclusions}

In this study, overtopping risk on a dike with gentle and shallow foreshores is investigated using SWASH, a NLSW equation solver. The model has been validated in different studies applied for shallow foreshores but it is further validated in terms of maximum individual volume based on a physical model. One of the benefits to use SWASH in this study is that the model can output $h$ and $u$ in time series while measurement of $u$ on a dike in physical model test is often a challenge. Using SWASH, the risk on the dike can be evaluated in details, in function of time. On top, SWASH is relatively a light wave model, and thus it is possible to obtain overtopping flows in different wave conditions and bathymetries: in this study total $\sim 200$ cases are simulated.

It is often the case in practice that the coastal safety is evaluated by the average overtopping discharge and maximum individual volume $V_{\max }$. However, it becomes clear from this study that overtopping risk is not only characterized by $q$ and $V$ : time dependent $h$ and $\mathrm{u}$ are also useful and even better parameters to characterize risks on dikes more in details. For instance, two cases in the example of this study show different $h$, even though the two cases show very similar $q$ and $V_{\max }$. This was due to the influence of the promenade which made $\mathrm{h}$ smaller and the duration longer. It is noted that the combination of stand-alone $\mathrm{h}_{\max }$ and $\mathrm{u}_{\max }$ can lead an overestimation of the hazard and therefore time dependent $\mathrm{h}$ and $\mathrm{u}$ are better for the proper assessment.

In addition to the overtopping flow on plain dikes, the influence of a vertical wall at the end of the promenade is also evaluated in this study. The results show that the vertical wall can influence on the people's safety on the promenade in a negative way. The bore can create a higher flow depth compared to the case without a vertical wall and it becomes an extra risk o. Depending on the position on the promenade, a relatively high negative velocity was also observed in the simulation.

Further study of the characterization of overtopping waves, such as cases with deep water conditions, storm walls on the dike, and vegetation in front of and on the dike [31], will be useful since a proper assessment of wave overtopping is an essential key for designing coastal structures which provides safety for people in coastal areas. Numerical modelling is a strong tool to evaluate risks in different scenarios.

Author Contributions: Conceptualization, T.S.; methodology, T.S., C.A., and T.Y.; analysis, T.S.; investigation, T.S.; writing — original draft preparation, T.S.; writing—review and editing, C.A., T.Y, and T.V.; visualization, T.S.; supervision, T.V.; project administration, T.V. All authors have read and agreed to the published version of the manuscript.

Funding: This research was part of the CREST (Climate REsilient CoaST) project (http://www.crestproject.be/en), funded by the Flemish Agency for Innovation by Science and Technology, grant number 150028. Corrado Altomare acknowledges funding from the European Union's Horizon 2020 research and innovation programme under the Marie Sklodowska-Curie grant agreement No.: 792370.

Conflicts of Interest: The authors declare no conflict of interest. The funders had no role in the design of the study; in the collection, analyses, or interpretation of data; in the writing of the manuscript, or in the decision to publish the results.

\section{References}

1. Weisse, R.; von Storch, H.; Niemeyer, H.D.; Knaack, H. Changing North Sea storm surge climate: An increasing hazard? Ocean Coast. Manag. 2012, 68, 58-68. [CrossRef]

2. Neumann, B.; Vafeidis, A.T.; Zimmermann, J.; Nicholls, R.J. Future coastal population growth and exposure to sea-level rise and coastal flooding - A global assessment. PLoS ONE 2015, 10. [CrossRef] [PubMed] 
3. Endoh, K.; Takahashi, S. Numerically Modeling Personnel Danger on a Promenade Breakwater Due to Overtopping Waves. In Proceedings of the 24th International Conference on Coastal Engineering, Kobe, Japan, 23-28 October 1994; pp. 1016-1029.

4. Sandoval, C.; Bruce, T. Wave overtopping hazard to pedestrians: Video evidence from real accidents. In Coasts, Marine Structures and Breakwaters 2017; Thomas Telford Ltd.: Liverpool, UK, 2018; pp. 501-512.

5. Allsop, N.W.H.; Bruce, T.; Pullen, T.; van der Meer, J. Direct Hazards from Wave Overtopping-The Forgotten Aspect of Coastal Flood Risk Assessment? In Proceedings of the 43rd Defra Flood and Coastal Management Conference, Manchester, UK, 1-3 July 2008; pp. 1-11.

6. Altomare, C.; Gironella, X.; Suzuki, T.; Viccione, G.; Saponieri, A. Overtopping metrics and coastal safety: A case of study from the catalan coast. J. Mar. Sci. Eng. 2020, 8, 556. [CrossRef]

7. Arrighi, C.; Oumeraci, H.; Castelli, F. Hydrodynamics of pedestrians' instability in floodwaters. Hydrol. Earth Syst. Sci. 2017, 21, 515-531. [CrossRef]

8. Arrighi, C.; Pregnolato, M.; Dawson, R.J.; Castelli, F. Preparedness against mobility disruption by floods. Sci. Total Environ. 2019, 654, 1010-1022. [CrossRef]

9. Schüttrumpf, H.; Oumeraci, H. Scale and Model Effects in Crest Level Design. In Proceedings of the 2nd Coastal Symposium, Höfn, Iceland, 5-8 June 2005; pp. 1-12.

10. Nørgaard, J.Q.H.; Lykke Andersen, T.; Burcharth, H.F.; Steendam, G.J. Analysis of overtopping flow on sea dikes in oblique and short-crested waves. Coast. Eng. 2013, 76, 43-54. [CrossRef]

11. Mares-Nasarre, P.; Argente, G.; Gómez-Martín, M.E.; Medina, J.R. Overtopping layer thickness and overtopping flow velocity on mound breakwaters. Coast. Eng. 2019, 154. [CrossRef]

12. van Bergeijk, V.M.; Warmink, J.J.; van Gent, M.R.; Hulscher, S.J. An analytical model of wave overtopping flow velocities on dike crests and landward slopes. Coast. Eng. 2019, 149, 28-38. [CrossRef]

13. Chen, X.; Jonkman, S.N.; Pasterkamp, S.; Suzuki, T.; Altomare, C. Vulnerability of buildings on coastal dikes due to wave overtopping. Water (Switz.) 2017, 9, 394. [CrossRef]

14. Van der Meer, J.W.; Allsop, N.W.; Bruce, T.; De Rouck, J.; Kortenhaus, A.; Pullen, T.; Schüttrumpf, H.; Troch, P.; Zanuttigh, B. Manual on Wave Overtopping of Sea Defences and Related Structures. An Overtopping Manual Largely Based on European Research, but for Worldwide Application, 2nd ed.; EurOtop: London, UK, 2018.

15. Altomare, C.; Suzuki, T.; Chen, X.; Verwaest, T.; Kortenhaus, A. Wave overtopping of sea dikes with very shallow foreshores. Coast. Eng. 2016, 116, 236-257. [CrossRef]

16. Suzuki, T.; Altomare, C.; Veale, W.; Verwaest, T.; Trouw, K.; Troch, P.; Zijlema, M. Efficient and robust wave overtopping estimation for impermeable coastal structures in shallow foreshores using SWASH. Coast. Eng. 2017, 122. [CrossRef]

17. Lashley, C.H.; Bricker, J.D.; Bricker, J.D.; Van Der Meer, J.; Van Der Meer, J.; Altomare, C.; Altomare, C.; Suzuki, T.; Suzuki, T. Relative Magnitude of Infragravity Waves at Coastal Dikes with Shallow Foreshores: A Prediction Tool. J. Waterw. Port Coast. Ocean Eng. 2020, 146, 1-17. [CrossRef]

18. Zijlema, M.; Stelling, G.; Smit, P. SWASH: An operational public domain code for simulating wave fields and rapidly varied flows in coastal waters. Coast. Eng. 2011, 58, 992-1012. [CrossRef]

19. Smit, P.; Zijlema, M.; Stelling, G. Depth-induced wave breaking in a non-hydrostatic, near-shore wave model. Coast. Eng. 2013, 76, 1-16. [CrossRef]

20. Suzuki, T.; De Roo, S.; Altomare, C.; Zhao, G.; Kolokythas, G.K.; Willems, M.; Verwaest, T.; Mostaert, F. Toetsing Kustveiligheid 2015-Methodologie: Toetsingsmethodologie Voor Dijken en Duinen; WL Rapporten; 10.0; Waterbouwkundig Laboratorium: Antwerpen, Belgium, 2016.

21. Rijnsdorp, D.P.; Smit, P.B.; Zijlema, M. Non-hydrostatic modelling of infragravity waves under laboratory conditions. Coast. Eng. 2014, 85, 30-42. [CrossRef]

22. Vasarmidis, P.; Stratigaki, V.; Suzuki, T.; Zijlema, M.; Troch, P. Internal wave generation in a non-hydrostatic wave model. Water (Switz.) 2019, 11, 986. [CrossRef]

23. Altomare, C.; Suzuki, T.; Verwaest, T. Influence of directional spreading on wave overtopping of sea dikes with gentle and shallow foreshores. Coast. Eng. 2020, 157, 103654. [CrossRef]

24. Tortora, S. Statistical characterisation of overtopping volumes for sea dikes in very shallow foreshore condition under short- and long-crested waves action. Master Thesis, University of L'Aquila, Rome, Italy, 2018.

25. Suzuki, T.; Altomare, C.; De Roo, S.; Vanneste, D.; Mostaert, F. Manning's Roughness Coefficient in SWASH: Application to Overtopping Calculation; FHR reports; Version 2; Flanders Hydraulics Research: Antwerp, Belgium, 2018. 
26. Oppenheimer, M.; Glavovic, B.; Hinkel, J.; van de Wal, R.; Magnan, A.K.; Abd-Elgawad, A.; Cai, R.; Cifuentes-Jara, M.; Deconto, R.M.; Ghosh, T.; et al. Sea Level Rise and Implications for Low-Lying Islands, Coasts and Communities. In IPCC Special Report on the Ocean and Cryosphere in a Changing Climate; Pörtner, H.-O., Roberts, D.C., Masson-Delmotte, V., Zhai, P., Tignor, M., Poloczanska, E., Mintenbeck, K., Alegría, A., Nicolai, M., Okem, A., et al., Eds.; In press.

27. Chen, X.; Hofland, B.; Altomare, C.; Suzuki, T.; Uijttewaal, W. Forces on a vertical wall on a dike crest due to overtopping flow. Coast. Eng. 2015, 95, 94-104. [CrossRef]

28. Streicher, M.; Kortenhaus, A.; Marinov, K.; Hirt, M.; Hughes, S.; Hofland, B.; Scheres, B.; Schüttrumpf, H. Classification of bore patterns induced by storm waves overtopping a dike crest and their impact types on dike mounted vertical walls-A large-scale model study. Coast. Eng. J. 2019, 61, 321-339. [CrossRef]

29. Gruwez, V.; Altomare, C.; Suzuki, T.; Streicher, M.; Cappietti, L.; Kortenhaus, A.; Troch, P. Validation of RANS Modelling for Wave Interactions with Sea Dikes on Shallow Foreshores Using a Large-Scale Experimental Dataset. J. Mar. Sci. Eng. 2020, 8, 650. [CrossRef]

30. Altomare, C.; Crespo, A.J.C.; Domínguez, J.M.; Gómez-Gesteira, M.; Suzuki, T.; Verwaest, T. Applicability of Smoothed Particle Hydrodynamics for estimation of sea wave impact on coastal structures. Coast. Eng. 2015, 96, 1-12. [CrossRef]

31. Suzuki, T.; Hu, Z.; Kumada, K.; Phan, L.K.; Zijlema, M. Non-hydrostatic modeling of drag, inertia and porous effects in wave propagation over dense vegetation fields. Coast. Eng. 2019, 149, 49-64. [CrossRef]

(C) 2020 by the authors. Licensee MDPI, Basel, Switzerland. This article is an open access article distributed under the terms and conditions of the Creative Commons Attribution (CC BY) license (http://creativecommons.org/licenses/by/4.0/). 